OPEN ACCESS

Citation: Anoop Puthuparampil Balan, Aloor Jose Robi, Nanu Sasidharan (2021) Argostemma quarantena (Rubiaceae, Ruboideae), a new species from southern Western Ghats, India. Webbia. Journal of Plant Taxonomy and Geography 76(1): 47-52. doi: 10.36253/jopt9592

Received: August 11, 2020

Accepted: October 20, 2020

Published: April 27, 2021

Copyright: @2021 Anoop Puthuparampil Balan, Aloor Jose Robi, Nanu Sasidharan. This is an open access, peerreviewed article published by Firenze University Press (http://www.fupress. com/webbia) and distributed under the terms of the Creative Commons Attribution License, which permits unrestricted use, distribution, and reproduction in any medium, provided the original author and source are credited.

Data Availability Statement: All relevant data are within the paper and its Supporting Information files.

Competing Interests: The Author(s) declare(s) no conflict of interest.

Editor: Riccardo M. Baldini

ORCID

APB: https://orcid.org/0000-0002-0608970X

AJB: https://orcid.org/0000-0001-58915658

\section{Argostemma quarantena (Rubiaceae, Ruboideae), a new species from southern Western Ghats, India}

\author{
Anoop Puthuparampil Balan ${ }^{1, *}$, Aloor Jose Robi ${ }^{2}$, Nanu Sasidharan ${ }^{3}$ \\ ${ }^{1}$ KSCSTE-Malabar Botanical Garden and Institute for Plant Sciences, Kozhikode, Kerala, \\ India \\ ${ }^{2}$ Department of Botany, Bishop Abraham Memorial College, Thuruthicad, Pathanamthit- \\ ta, Kerala, India \\ ${ }^{3}$ Kerala Forest Research Institute, Peechi, Thrissur, Kerala, India \\ ${ }^{\star}$ Corresponding author. E-mail: anooppb01@gmail.com
}

\begin{abstract}
Argostemma quarantena, a new rubiaceous species from Vagamon Hills of southern Western Ghats, India is described and illustrated here. The species shows similarities with two south Indian endemics, A. anupama and A. courtallense, but differs in many qualitative attributes. The present status of genus Argostemma in India is briefly discussed. An artificial key for the identification of Argostemma in Western Ghats is also provided.
\end{abstract}

Keywords: Argostemmateae, Epilithic, Kottayam, Vagamon Hills.

\section{INTRODUCTION}

Argostemma Wall., is a genus of small perennial herbs, widely distributed in tropical and sub-tropical Asia, except for two African species namely, $A$. africanum K.Schum. and A. pumilum Benn. (Sridith 1999; Sridith and Puff 2000). It is one of the four genera of the tribe Argostemmateae of subfamily Ruboideae (Rydin et al. 2009). Wallich (in Roxburgh 1824) described the genus Argostemma based on the species A. sarmentosum from the former British India. He also described three more species in the same publication, viz., A. rostratum \& A. verticillatum from subtropical Himalaya and A. pictum from Malaya. In the ensuing years, many new species were added to the genus and presently Argostemma comprises 100 to 200 species (100: Mabberley 2017; 165: The Plant List 2013; 175: WCSP 2020; 220: Bremer 1989; Bremer and Manen 2000) with highest concentration in South East Asia. A dozen of new species have been added to the genus from S.E. Asia over the last 10 years (Sridith 2012; Choudhary et al. 2013; Lanorsavanh and Chantaranothai 2016; Nuraliev et al. 2017; Quang et al. 2019; Hsu et al. 2020; Lanorsavanh et al. 2020; Van Do et al. 2020). 
The species of Argostemma are frequently lithophytic, or occasionally epiphytic inhabiting moist to wet places with high humidity, on wet rock faces by waterfalls, or on large boulders in or along streams (Sridith and Puff 2000). Flowers of Argostemma are either star-shaped or bell-shaped with free stamens or stamens of which the anthers may be coherent into a cone-like structure (Sridith and Puff 2001; Sridith 2007). Argostemma diversifolium Ridl. and A. separatum Aranas, H.W.C. Hsu, \& Alejandro are the only known species in the genus with free stamens in star-shaped corolla (Sridith 2007; Hsu et al. 2020).

Argostemma is one of the least studied rubiaceous genus in India. After Hooker (1880), no one attempted a comprehensive systematic treatment of the genus in India. Hooker included 17 species of Argostemma in the Flora of British India which covers the areas of present day India, Pakistan, Afghanistan, Nepal, Tibet, Bangladesh, Burma (Myanmar), Ceylon (Sri Lanka) and Malayan Peninsula, out of which 7 species were described from the present day political boundaries of India, viz., A. courtallense Arn., A. humile Benn., A. khasianum C.B.Clarke, A. pumilum Benn., A. rostratum Wall., A. sarmentosum Wall. and A. verticillatum Wall. Later, A. neurocalyx Miq., A. tavoyanum Wall. ex Benn. and A. timorense Benn. from Andaman \& Nicobar Islands and A. Anupama Sivar. From the Western Ghats were added to the Indian flora (Vasudeva Rao 1986; Pandey and Diwakar 2008; Sivarajan, 1984; Jayanthi et al. 2013).

In the Western Ghats, the genus is represented by four species, namely, A. anupama, A. courtallense, A. rostratum and $A$. verticillatum (Nayar et al. 2014). Deb and Basu (1990) reduced A. anupama and A. tavoyanum as synonyms to A. courtallense. Later, Sridith (1999) reinstated the status of $A$. tavoyanum and Sivarajan and Pradeep (1993) did the same for A. anupama. Thus, the genus Argostemma in India is presently represented by 11 species, chiefly distributed in North East India and Western Ghats. During a floristic exploration in the Vagamon Hills in southern Western Ghats, India, the authors encountered an interesting species of Argostem$m a$, notable due to its densely hairy, strongly anisophyllous leaves and much short, congested umbels. Detailed study of the literature (Hooker 1880; Gamble 1921; Ridley 1923 and 1927; Bremer 1989; Sridith 1999; Chen et al. 2011) and comparison of type specimens of Indian species in major herbaria in India (CAL, CALI, MH) and abroad (BM, K, etc.) revealed that the unknown taxon is morphologically similar to A. anupama and A. courtallense, but shows distinct differences as shown in table 1 . Hence, it is described and illustrated here as a new species from India.
Argostemma quarantena Balan \& Robi, sp. nov. (Figures 1 and 2)

Type: INDIA, Kerala, Kottayam district, Vagamon Hills, $\pm 1000 \mathrm{~m}, 12$ July 2020, A.J.Robi \& Anoop P.B. 15561 (holotype, MH!; isotypes, MBGH!, MH!).

\section{Diagnosis}

The new species is closely similar to A. anupama, but differs in it stem (suberect, terete stem vs erect, quadrangular stem), stipules (1.5-2.0 mm long, deltate stipules vs c. $1 \mathrm{~mm}$ long, ovate stipules), leaves (obovate-oblanceolate, densely strigose lamina with $6-10$ pairs veins vs ovate-lanceolate, scabrous lamina with 4-6 pairs veins), length and form of umbel (c. $1.5 \mathrm{~cm}$ long, congested umbel vs $2.5-3.5 \mathrm{~cm}$ long, lax umbel), pedicels $(2-3 \mathrm{~mm}$ long, stout, hirsute pedicels vs $8-10 \mathrm{~mm}$, slender, pubescent pedicels), calyx lobes ( $2.5 \mathrm{~mm}$ long vs $4.0 \mathrm{~mm}$ long), corolla lobes (4.5 mm long, triangular vs 5.5-6.0 $\mathrm{mm}$ long, lanceolate) and anther filaments (not twisted vs twisted). It also shows similarities with $A$. courtallense, but differs mainly by its stipules $(1.5-2.0 \mathrm{~mm}$ long, deltate stipules vs $7-8 \mathrm{~mm}$ long, ovate stipules), shape and indumentum of leaves (anisophyllous leaves with obovate-oblanceolate and densely strigose lamina vs isophyllous leaves with ovate-orbicular and sparsely pubescent lamina), number of lateral veins (6-10 pairs vs $4-7$ pairs lateral veins), umbel (c. $2 \mathrm{~cm}$ long, congested umbel vs 4-8 cm long, lax umbel), corolla lobes (4-4.5 $\mathrm{mm}$ long vs $7-8 \mathrm{~mm}$ long) and anthers (ca $1.5 \mathrm{~mm}$ long, white anthers vs ca $3 \mathrm{~mm}$ long, yellow anthers). (Table 1).

\section{Description}

Epilithic, perennial herb, 3-7 cm tall; attached to the substrate with dense, much-branched matted roots. Tuber 4-5 $\times 3-4 \mathrm{~mm}$, ovoid. Stem suberect, unbranched, terete, $1.5-4 \mathrm{~cm}$ long, glabrous, succulent. Stipule deltate, $1.5-2 \times 1.5-2 \mathrm{~mm}$, hairy along margins, deciduous. Leaves opposite, $2-3$ pairs, upper 4 pseudoverticillate, strongly anisophyllous, mostly subfalcate; petiole 3-4 mm long, hairy; large leaf blade narrowly obovate-oblanceolate or elliptic, $5-9 \times 1.2-2.5$ $\mathrm{cm}$, small leaf blade ovate-elliptic, 1.5-4.5 × 0.6-1.5 $\mathrm{cm}$, membraneous, acute to shortly acuminate at apex, cuneate at base, inequilateral, densely strigose above, so below along the veins; venation brochidodromous, veins 6-10 pairs, raised below. Inflorescence solitary, terminal, 6 to 10 -flowered, much congested, pedunculate umbel; peduncle $0.5-1.3 \mathrm{~cm}$ long, much shorter than leaf, unbranched, glabrous. Flowers 4-merous, actinomorphic; bracts $4-6$, of unequal size, fused basally and forming a cup-like involucrum, each bract ovate, 4-5 

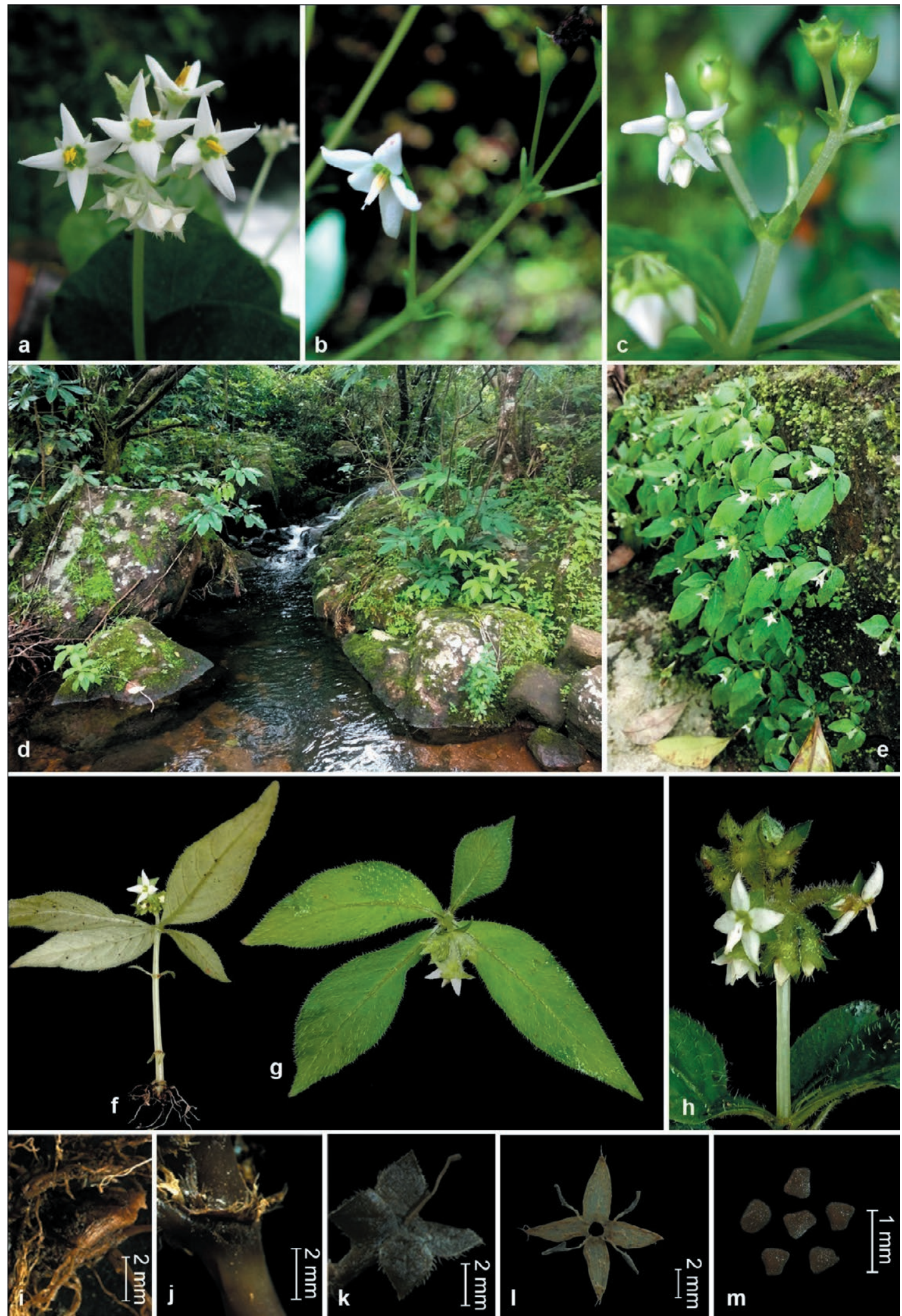

Figure 1. (a) Argostemma courtallense. (b) A. rostratum. (c) A. verticillatum. (d, e) A. quarantena sp. nov., Habitat. (f, g) Habit. (h) Inflorescence. (i) Tuber. (j) Stipule. (k) Calyx with pistil. (l) Corolla and stamens. (m) Seeds. 


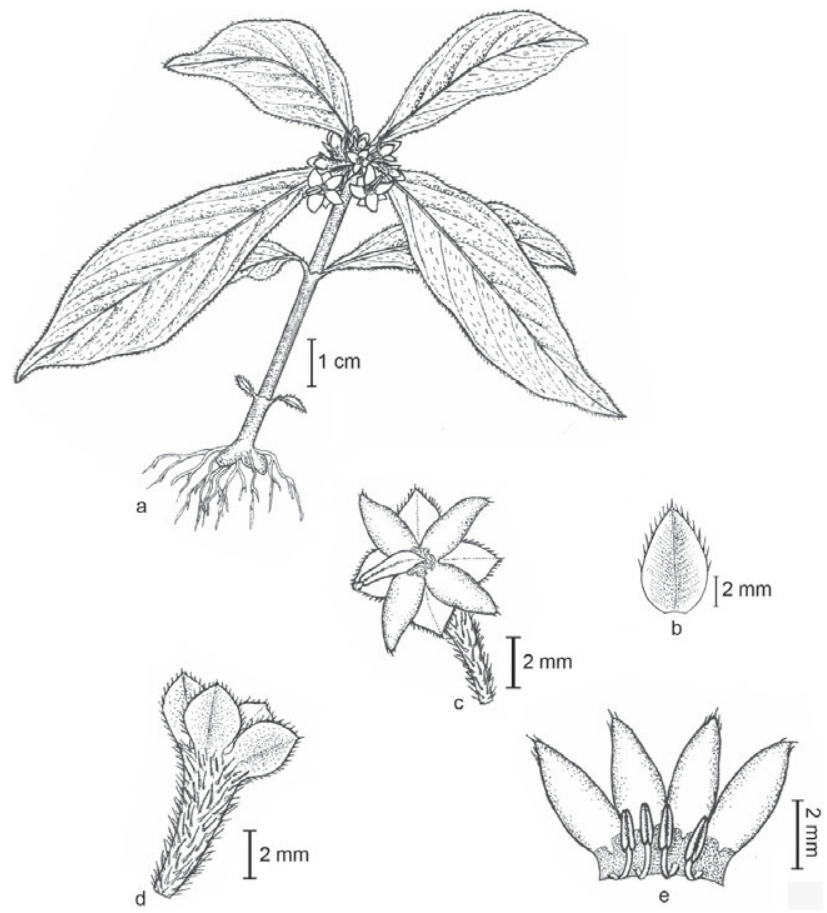

Figure 2. Argostemma quarantena. sp. nov. (a) Habit. (b) Bract. (c) Flower. (d) Calyx. (e) Split opened corolla. Drawn by Anoop P. Balan. $\times 4-5 \mathrm{~mm}$, acute at apex, hairy along margins, green; pedicels 2-3 $\mathrm{mm}$ long, stout, dilated above, densely hirsute. Calyx campanulate, tube short, densely hirsute; lobes 4 , ovate, $2.5 \times 2.5 \mathrm{~mm}$, acute at apex, hairy along margins, spreading, enlarged in fruit, venation inconspicuous. Corolla white with green blotches at base of the tube, star-shaped; corolla tube $0.6-0.8 \mathrm{~mm}$ long; corolla lobes triangular-lanceolate, $4-4.5 \times 2-2.5 \mathrm{~mm}$, spreading, with a tuft of hairs at back towards apex. Stamens 4, filaments free, inserted at the base of the corolla tube, ca $1.5 \mathrm{~mm}$ long, bent at the middle, white; anthers connivent in a cone around the stigma, oblong, as long as filament, opening by apical pores, white. Ovary inferior, 2-locular, many-ovuled; style slightly exserted from the stamens, ca $3 \mathrm{~mm}$ long, stout, glabrous; stigma clavate. Fruit capsular, opening by an apical operculum, subglobose, 3-4 × 3-4 mm, densely hairy, crowned by persistent calyx. Seeds many, $0.3-0.4 \times 0.2-0.3 \mathrm{~mm}$, angled and minutely tuberculate, pale brown.

\section{Etymology}

The specific epithet quarantena indicates the outbreak of COVID-19 corona virus across the world in 2020 . The term quarantena was used in $14^{\text {th }}-15^{\text {th }}$ century Venetian language for a forty-day isolation period. The

Table 1. Comparison of Argostemma quarantena sp. nov. with A. anupama and A. courtallense.

\begin{tabular}{|c|c|c|c|}
\hline Attributes & A. quarantena & A. апирата & A. courtallense \\
\hline Stem & Suberect, terete, glabrous, $3-7 \mathrm{~cm}$ tall. & $\begin{array}{l}\text { Erect, quandrangular, puberulous, } 2-6 \\
\mathrm{~cm} \text { tall. }\end{array}$ & Erect, terete, pubescent, $8-20 \mathrm{~cm}$ tall. \\
\hline Stipule & Deltate, $1.5-2 \times 1.5-2 \mathrm{~mm}$ & Ovate, c. $1 \times 0.5 \mathrm{~mm}$, minute & Ovate, $7-8 \times 1-2 \mathrm{~mm}$. \\
\hline Leaves & $\begin{array}{l}2-3 \text { pairs, strongly anisophyllous; } \\
\text { lamina narrowly obovate-oblanceolate } \\
\text { or elliptic, } 1.5-10 \times 0.6-2.5 \mathrm{~cm} \text {, cuneate } \\
\text { and unequal at base, acute to shortly } \\
\text { acuminate at apex, densely strigose on } \\
\text { both surfaces, pale grey-glaucous below. }\end{array}$ & $\begin{array}{l}2-3 \text { pairs, anisophyllous; lamina ovate- } \\
\text { lanceolate, } 2-9 \times 1-1.8 \mathrm{~cm} \text {, cuneate and } \\
\text { unequal at base, acute at apex, scabrous } \\
\text { on both surfaces, white-glaucous below. }\end{array}$ & $\begin{array}{l}2 \text {-pairs, isophyllous; lamina ovate- } \\
\text { orbicular, } 8-12 \times 5-8 \mathrm{~cm} \text {, subacute or } \\
\text { rounded and equal at base, acute at apex, } \\
\text { sparsely pubescent on both surfaces, } \\
\text { white-glaucous below. }\end{array}$ \\
\hline Petiole & 3-4 mm long. & 5-6 mm long & $0-2 \mathrm{~cm}$ long. \\
\hline Venation & 6-10 pairs. & 4-6 pairs & 4-7 pairs. \\
\hline Bract & $4-6$, ovate, $4-5 \times 4-5 \mathrm{~mm}$ & $4-5$, ovate, $3-4 \times 1.5-2.5 \mathrm{~mm}$ & 4 , ovate, $4.0 \times 2.5 \mathrm{~mm}$ \\
\hline Inflorescence & $\begin{array}{l}6-10 \text { flowered, much congested; } \\
\text { peduncle } 0.5-1.3 \mathrm{~cm} \text { long. }\end{array}$ & $\begin{array}{c}\text { 6-8 flowered, lax; peduncle } 2.0-3.5 \mathrm{~cm} \\
\text { long. }\end{array}$ & $\begin{array}{c}\text { 3-many flowered, lax; peduncle } 3-6 \mathrm{~cm} \\
\text { long. }\end{array}$ \\
\hline Pedicel & $2-3 \mathrm{~mm}$ long, stout, densely hirsute. & 8-10 mm long, slender, pubescent. & 8-10 mm long, slender, pubescent. \\
\hline Flower & 4-merous. & 4-5- merous & 4-merous. \\
\hline Calyx & $\begin{array}{c}\text { Lobes } 4 \text {, ovate, } 2.5 \times 2.5 \mathrm{~mm} \text {, with } \\
\text { rounded sinuses. }\end{array}$ & $\begin{array}{l}\text { Lobes } 4-5 \text {, ovate, } 4 \times 3 \mathrm{~mm} \text {, with } \\
\text { rounded sinuses }\end{array}$ & $\begin{array}{c}\text { Lobes } 4 \text {, ovate, } 3 \times 2 \mathrm{~mm} \text {, with acute } \\
\text { sinuses. }\end{array}$ \\
\hline Corolla & $\begin{array}{l}\text { Lobes } 4 \text {, triangular lanceolate, } 4-4.5 \times \\
\qquad 2-2.5 \mathrm{~mm}\end{array}$ & $\begin{array}{l}\text { Lobes } 4-5 \text {, elliptic-lanceolate, } 5.5-6 \times \\
\qquad 2-2.5 \mathrm{~mm} .\end{array}$ & Lobes 4 , ovate, $7-8 \times 2-2.5 \mathrm{~mm}$. \\
\hline Stamens & $\begin{array}{c}\text { 4, filaments ca } 1.5 \mathrm{~mm} \text { long, free, bent } \\
\text { at middle; anthers white, oblong, ca } 1.5 \\
\text { mm long. }\end{array}$ & $\begin{array}{l}\text { 4-5, filaments ca } 2 \mathrm{~mm} \text { long, free, twisted; } \\
\text { anthers white, oblong, ca } 2 \mathrm{~mm} \text { long. }\end{array}$ & $\begin{array}{l}\text { 4, filaments } 3 \mathrm{~mm} \text { long, free, bent at } \\
\text { middle; anthers yellow, lanceolate, ca } 3 \\
\text { mm long. }\end{array}$ \\
\hline
\end{tabular}


new species was described during the 2020 quarantine period imposed to curb the spread of the COVID-19 virus. This species is a dedication to the lakhs of people including eminent botanists and scientists who have lost their lives due to the COVID-19 virus in the year 2020.

\section{Phenology}

July to September

\section{Distribution and ecology}

Argostemma quarantena is known only from its type locality at Vagamon Hills, South India. Vagamon hills are traversed by numerous perennial fast flowing streams which originated from evergreen forest patches and pseudosholas at 1000-1400 m elevations asl. This species is thriving on boulders beside such streams and shaded areas, growing with mosses and ferns.

\section{Conservation status}

Argostemma quarantena is so far known only from the type locality, Vagamon Hills of Western Ghats, with an extent of occurrence estimated to be less than $10 \mathrm{~km}^{2}$. The authors located 5 groups of fewer than 100 plants along the streams. Argostemma spp. are normally found in wet, shady, undisturbed habitats and are very sensitive to microclimatic changes (Sridith \& Puff, 2000). The type locality of $A$. quarantena is outside of protected forest areas and is under threat due to habitat loss as a result of human encroachment. Extensive field surveys are needed to assign appropriate threatened category of IUCN (2012), therefore it is classified as Data Deficient (DD) according to IUCN standards.

\section{Paratype}

INDIA: Kerala, Kottayam district, Vagamon Hills, $\pm 1000 \mathrm{~m}, 30$ July 2020, Anoop P.B. \& A.J.Robi \& 15562 (MBGH!, MH!).

Key to the identification of Argostemma in the Western Ghats

1a. Umbels branched; flowers 5-merous...... . .2

1b. Umbels unbranched; flowers 4-merous (except A. anupa$m a)$

2a. Leaves 2 pairs; peduncle much shorter than the leaves ........ A. verticillatum

2b. Leaves 3 pairs; peduncle as long as the leaves A. rostratum

3a. Leaves 2-3 pairs, anisophyllous; anthers white 3b. Leaves 2 pairs, isophyllous; anthers yellow A. courtallense

4a. Stem terete; lamina densely strigose with 6-10 pairs veins; pedicels $<5 \mathrm{~mm}$ long

A. quarantena

4b. Stem quadrangular; lamina scabrous with 4-6 pairs veins; pedicels $>8 \mathrm{~mm}$ long A. anupama

\section{REFERENCES}

Bremer B. 1989. The genus Argostemma (RubiaceaeArgostemmateae) in Borneo. Ann Missouri Bot Gard. 76 (1): 7-49. https://doi.org/10.2307/2399341

Bremer B, Manen SF. 2000. Phylogeny and classification of the subfamily Rubioideae (Rubiaceae). Plant Syst Evol. 225: 43-72.

Chen T, Zhu H, Chen J, Taylor CM, Ehrendorfer F, Lantz H, Funston AM, Puff C. 2011. Rubiaceae. In: Wu ZY, Raven PH, Hong DY (Eds.) Flora of China, 19. Science Press and Missouri Botanical Garden, Beijing and St. Louis. p. 57-368.

Choudhary RK, Bach TT, Hai DV, Quang BH, Park SangHong, Lee C, Lee J. 2013. Argostemma glabra (Rubiaceae), a new species from Vietnam. Ann. Bot. Fenn. 50: 258-262. https://doi.org/10.5735/086.050.0408

Deb DB, Basu SK. 1990. Changes in the status of two species in the genus Argostemma (Rubiaceae). J Bombay Nat Hist Soc. 87: 332.

Gamble JS. 1921. Flora of the Presidency of Madras. Adlard \& Sons Ltd., London. p. 590-591.

Hooker JD. 1880. Argostemma. In: The Flora of British India, vol 3. Reeve \& Co., London. p. 42-46.

Hsu HWC, Aranas DR, Alejandro JD, Liede-Schumann S. 2020. A new species of Argostemma (Rubiaceae) with free stamens in star-shaped corolla from the Philippines. Phytotaxa. 437(2): 113-117. https://doi. org/10.11646/phytotaxa.437.2.7

IUCN Standards and Petitions Subcommittee. 2019. Guidelines for using the IUCN Red List categories and criteria version 14. Standards and Petitions Subcommittee. Available from: http://www.iucnredlist. org/documents/RedListGuidelines.pdf (accessed 08 July 2020)

Jayanthi J, Karthigeyan K, Sumathi R. 2013. Argostemma timorense - A New addition to Indian Rubiaceae from Great Nicobar Island. Taiwania. 58(3): 226-228.

Lanorsavanh S, Chantaranothai P, Souvannakhoummane K. 2020. Six new species of Argostemma Wall. (Rubiaceae) from Laos. Nordic J Bot. e02714. https://doi. org/10.1111/njb.02714

Lanorsavanh S, Chantaranothai P. 2016. Argostemma laotica (Rubiaceae), a new species from Laos. Phtotaxa. 
270(3): 223-226. http://dx.doi.org/10.11646/phytotaxa.270.3.7

Mabberley DJ. 2017. The Plant Book. $3^{\text {rd }}$ ed. Cambridge University Press, Cambridge. 65pp.

Nayar TS, Beegam AR, Sibi M. 2014. Flowering Plants of the Western Ghats, India, vol. 1. Jawaharlal Nehru Tropical Botanic Garden and Research Institute, Thiruvananthapuram. p. 765-766.

Nuraliev MS, Beer AS, Kuznetsov AN, Kuznetsova SP. 2017. Argostemma cordatum (Rubiaceae), a new species from Vietnam. Phytotaxa. 317(1): 042-052. https://doi.org/10.11646/phytotaxa.317.1.4

Pandey RP, Diwakar PG. 2008. An integrated checklist flora of Andaman \& Nicobar Islands, India. J Econ Tax Bot. 32: 403-500.

Quang BH, Choudhary RK, Bach TT, Hai DV, Cuong NT, Lee J. 2019. Argostemma vietnamicum (Rubiaceae), a new species from Vietnam. Ann Bot Fenn. 56(1-3): 27-31. https://doi.org/10.5735/085.056.0105

Ridley HN. 1923. The Flora of the Malay Peninsula. Reeve \& Co., Ltd., London. p. 21-35.

Ridley HN. 1927. The genus Argostemma. J Bot. (London) 65: 25-41.

Rydin C, Razafimandimbison SG, Khodabandeh A, Bremer B. 2009. Evolutionary relationships in the Spermacoceae Alliance (Rubiaceae) using information from six molecular loci: Insights into systematic affinities of Neohymenopogon and Mouretia. Taxon 58: 793-810. https://doi.org/10.1002/tax.583009

Sridith K, Puff C. 2000. Distribution of Argostemma Wall. (Rubiaceae), with special reference to Thailand and surrounding areas. Thai Forest Bulletin, Botany. 28: 123-137.

Sridith K, Puff C. 2001. Floral diversity in Argostemma (Rubiaceae). In: Saw LG, Chua LSL, Khoo KC (Eds.). Taxonomy, the cornerstone of biodiversity. Proceedings of the Fourth International Flora Malesiana Symposium, 1998. Ampang Press Sdn. Bhd, Kuala Lumpur. p. 169-180.

Sridith K. 1999. A synopsis of the genus Argostemma Wall. (Rubiaceae) in Thailand. Thai Forest Bull Bot. 27: $86-137$.

Sridith K. 2007. Notes on the genus Argostemma (Rubiaceae) of the Malay Peninsula and Peninsular Thailand. Blumea. 52(2): 367-377. https://doi. org/10.3767/000651907X609115

Sridith K. 2012. Argostemma phyllocharis, a new species of Rubiaceae from Northern Thailand. Kew Bulletin. 67: 85-87. https://doi.org/10.1007/s12225-012-9326-Z

The Plant List. 2013. Version 1.1. Published on the Internet; http://www.theplantlist.org/ (accessed $8^{\text {th }}$ August 2020).
Van Do T, Chen Z, Yang N. 2020. Argostemma bachmaense (Rubiaceae, Rubioideae, Argostemmateae), a new species from central Vietnam. Nordic J Bot. e02765. DOI: 10.1111/njb.02765

Vasudeva Rao MK. 1986. A preliminary report on the angiosperms of Andaman and Nicobar Islands. J Econ Tax Bot. 8: 107-184.

Wallich N. 1824. In: Roxburgh W, Flora Indica or Descriptions of Indian Plants II. Serampore, Printed at the Mission Press. p. 324-327.

WCSP. 2020. 'World Checklist of Selected Plant Families. Facilitated by the Royal Botanic Gardens, Kew. Published on the Internet; http://wcsp.science.kew. org/ Retrieved. 